\title{
Action Learning: A Positive Predictor of Motivation and Commitment for Bankers in Pakistan
}

\author{
Faizan Mohsan (Corresponding author) \\ Hailey College of Commerce, University of the Punjab, Pakistan \\ Tel: 92-322-751-5556_E-mail: faizanmohsan@gmail.com \\ Muhammad Musarrat Nawaz \\ Hailey College of Commerce, University of the Punjab, Pakistan \\ E-mail: musaratnawaz@gmail.com \\ M. Sarfraz Khan \\ Hailey College of Commerce, University of the Punjab, Pakistan \\ E-mail: sarfrazkhalil@gmail.com \\ Zeeshan Shaukat \\ Hailey College of Commerce, University of the Punjab, Pakistan \\ E-mail: mzeeshan.shaukat@gmail.com
}

Received: June 4, 2011

Accepted: September 20, 2011

Published: January 16, 2012

doi:10.5539/ijbm.v7n2p252

URL: http://dx.doi.org/10.5539/ijbm.v7n2p252

\begin{abstract}
Action learning has been gaining increasing respect from the human resource researchers as a recognized field of scholarly study and is widely used by the organizations to develop practical management skills of employees in order to cope with future organizational problems effectively. The current research study aims to find out the role of action learning in predicting motivation and commitment for banking personnel. A questionnaire survey was conducted in banking sector of Pakistan. Data were collected from 285 subjects and then analyzed using the SPSS 16 and Microsoft Excel. A significant positive association of action learning was found out with employee motivation and commitment. Limitations of the study and implications for future research are also discussed.
\end{abstract}

Keywords: Action learning, Motivation, Commitment, Bankers, Pakistan

\section{Introduction}

Banking sector is considered as an important tier of a country's economic system and Pakistan is no exception. The demand of today's competitive corporate environment coupled with customers' increasing quality service expectations compel the financial institutions including banks to achieve higher levels of productivity and deliver quality services at the same time. To achieve such outcomes the major need of financial institutions is the availability of highly motivated and committed workforce because well managed and happy human resources are considered as root source of productivity and quality gains (Lord, 2002; Mohsan, Nawaz, \& Khan, 2011; Armstrong, 2006; DeCenzo, \& Robbins, 1996; Robbins, \& Coulter, 1996; Berman, Bowman, West, \& Wart, 2010; Kamery, 2004; Nelson, 1996). In response to this challenge financial institutions are providing action learning opportunities to the employees by enabling them to work on real issues, focusing on learning and implementing pragmatic solutions (Sandelands, 1998) which keep the employees motivated and enhance their commitment to the employers (McGill, \& Beaty, 2001; Cortada, \& Woods, 1999). As the financial institutions have shifted the training of human resources from working on simulated situations to real workplace problems, action learning has become an essential tool for human resource development.

The concept of action learning was first introduced in UK shortly after the World War II by the father of action learning Professor Reg Revans (Pounder, 2009). Action learning, also called special assignments, has been defined 
as a training technique by which a group of managers address current actual workplace problems or issues in complex situations in order to train them to better cope with tomorrow's problems (Raelin, 1997; Revans, 1980; Weinstein, 1998; Dilworth, \& Willis, 2003). It is a mutual learning process which brings trainees together to share, support as well as challenge each other in seeking to learning (Beaty, Lawson, Bourner, \& O'Hara, 1997; Pedler, 1996; Mercer, 1990; Mumford, 1995).

The importance of action learning in workplace is obvious as one of the pioneers of action learning, Reg Revans states that there can be no learning activity without action and no action without any learning activity (Revans, 1980). It holds great significance in almost every sphere of corporate environment. So how could banking sector remain devoid of it? Today, a growing concern expressed by banks is the failure of universities to provide students with the necessary skills needed by modern business and industry (Hibbert, 2000). Recognizing this failure, financial institutions are responding by introducing new and innovative approaches for training and development of human resources. One such approach is the adoption and implementation of action leaning (Frank, 1996).

Both the employees and their employers can extract fruits from action learning as it motivates the employees to develop practical management skills (Johnson, \& Spicer, 2006) in order to generate solutions for future organizational problems effectively (Revans, 1980; Mumford, 1995) as well as helps the organizations to cope with dynamic corporate changes successfully (O'Hara, Webber, \& Reeve, 1996), create a culture of innovation via problem-solving process and subsequently enhance organizational performance (Pounder, 2009).

By providing a brief overview of action learning literature and then discussing major challenges to be faced by the financial institutions, the current research study is aimed to open a dialog about action learning that would lead to the development of theoretical framework and empirical testing concerning the role of action learning in predicting motivation and commitment for bankers in Pakistan.

\section{Literature Review}

Over the past few decades, numerous studies have shed light on the role of action learning in predicting employee motivation and commitment (Eggers, Wooten, Childs, \& Coker, 2008; Moczuk, 2006; Cortada, \& Woods, 1999; Goh, 1998). An increase in competition in banking sector and greater allocation of resources for the development of action learning programs has stimulated this focus. Today, financial institutions don't look to capital investments but to human resources as the critical source of improvement. Productivity improvements require more than just better customer services, technology or process reengineering and the success of such initiatives is not possible without highly committed and motivated employees who are asked to implement them (Islam, \& Ismail, 2008) because when employees have motivation, they work with high morale, energy and enthusiasm whereas in case of lack of motivation, they accomplish less and seem to need more management assistance or supervision to do even a basic amount of work and overcome modest challenges (Berman, Bowman, West, \& Wart, 2010).

An effective and well reputed financial institution always make sure that there is a strong spirit of mutual cooperation and sense of motivation and commitment within all spheres of its influence; and to make the employees motivated and committed towards their jobs, there is a need for well-designed and effective action learning programs at various levels, sections and departments of the institution. Employee motivation argument is that action learning opportunities make the work more interesting (Knudsen, \& Smith, 1934; Wagner, \& Gooding, 1987; Baldwin, Magjuka, \& Loher, 1991; McGill, \& Beaty, 2001). According to Fernet, Senecal, Guay, Marsh and Dowson (2008), action learning is a potential solution to employees' lack of motivation as specific work tasks with some challenging problems improve the self-efficacy and self determination of employees as well as reduce the job burnout and turnover intensions. More recently, Ng, Butts, Vandenberg, Dejoy and Wilson (2006) have pointed out towards the increased loyalty and commitment as one of the benefits of action learning. They argued that organizations which provide their employees' action learning opportunities have more loyal and committed workforce as such opportunities serve as psychological stabilizing or obliging forces which bind employees to courses of actions that enhance their professional experiences and create feelings of successful learning among them which significantly enhance their commitment towards their respective organizations.

Action learning has been extolled as an effective managerial tool for enhancing employees' motivation at work since a long time. Pollanen (2007) stated that action learning opportunities with some challenging organizational issues greatly enhance employees' motivation levels and make them satisfied with their individual training outcomes. Cooper, Robinson and Patall (2003) also provided empirical evidence that action learning provides immediate feedback to employees; thus allowing their performance deficiencies to be corrected while the mistake is still fresh and enhance their motivation to learn and adapt new skills in order to tackle similar real workplace problems until they master the concept and have a superior performance. Action learning is a sort of reciprocal learning mechanism (Potter, \& Johnston, 2006) which provides timely feedback to employees and enhances their levels of motivation along with job performance (Eggers, Wooten, Childs, \& Coker, 2008; Katsanis, 2006). 
According to Moczuk (2006), action learning programs with some specific deadlines facilitate the employees with multiple information literacy sessions by their immediate bosses which enhance employees' motivation, encourage analytical thinking and incorporate lifelong learning among them that continues throughout a lifetime.

Dynamic and ever changing corporate environment coupled with increased globalization pressure compels the financial institutions to develop dream employees with high levels of skills, motivation and commitment through time to time action learning programs. Dream employees serve as assets in the form of sustainable competitive advantage and are critical to a financial institution's success. Nurturing the dream employees is a critical action learning activity to help retain these highly skilled and talented individuals as well as to make them feel appreciated so that they can perform to the ever best of their capacity which resultantly help the financial institutions to keep pace with technological advancements, cope with competitive pressures successfully and ultimately enhance profitability. Today financial institutions from all around the world enhance their employees' commitment by formulating and implementing management development programs, using action learning percepts that involve specific organizationally based challenges which employees must confront, resolve and implement within their unit of responsibility and enhance their professional experiences (Ferris, Rosen, \& Barnum, 1995; Cortada, \& Woods, 1999; Goh, 1998).

Action learning has become the prime methodology used by the global organizations for the development of employees and building corporate capabilities which make the employees feel that organization values their employees and resultantly make them more loyal and committed to the organization (Marquardt, 2004). McGill and Beaty (2001) also provided empirical evidence that action learning greatly enhances employees' commitment to an organization by facilitating the transfer of knowledge between the work teams as well as encouraging the employees to both act and learn at the same time in order to solve the complex and critical organizational issues and problems effectively. Action learning programs link the learning activities to real life business operations (Gilley, \& Maycunich, 2000) which facilitate well-tested methods of accelerating learning that enable employees to master and handle difficult real life situations and problems successfully and enhance employees' commitment to an organization (Marquardt, 1997).

To become effective financial services institutions as well as to meet the global challenges successfully, banks must be active and responsive to their human resources. They need to enhance employees' motivation and commitment through action learning opportunities in a climate in which employees feel appreciated, be happy to work and extract maximum pleasure from their work. Therefore, it becomes the goal of every financial institution of $21^{\text {st }}$ century to motivate its employees towards continuous action learning and to take advantage of this knowledge to ensure its survival in today's dynamic corporate environment (Osteraker, 1999).

\section{Research Methodology}

We used survey method for this study. The scale was developed to measure the extent of action learning in the bank's using five point likert scale, the reliability of the scale was accessed using Cronbach's Alpha, the scale was composed of four items and the Cronbach's Alpha score was .608 which indicates a good reliability of the scale. The employee motivation scale was adopted from (Mohsan, Nawaz, \& Khan, 2011) and had six items. On the other hand a fifteen item scale for employee commitment was adopted from Mowday and Steers (1979). All the scales were measured on five point likert scale. A demographics section was also included in the questionnaire containing questions with regard to gender, age, and work experience of the respondents and about the type and nature of the bank they are working for.

Initially a total of 400 questionnaires were distributed among the bankers across Punjab. 305 responses were received back and out of these 285 were found complete in all respect, which were used in data analysis. The analysis was done on SPSS 16 using descriptive and correlations.

\subsection{Theoretical Framework of the Study}

In view of the literature discussed, we can formulate following research model for the study.

\section{INSERT FIGURE 1 HERE}

\subsection{Hypothesis of the Study}

In view of the literature discussed, following hypothesis are developed:

H1: Action Learning has a significant relationship with employee motivation.

H2: Action Learning has a significant relationship with Employee commitment.

\section{Analysis and Interpretations}

Table 1 provides the demographical distribution of the respondents with regard to various categories. The respondents were distributed according to type of bank, nature of bank, their respective level of job, gender and 
their qualification. As provided by table out of a total 285 sample 261 respondents belonged to the private banks while remaining 24 were from private banks, the reason for the lower ratio of respondents from public bank is that only one bank i.e. National Bank of Pakistan is public in the recent era. The ratio of respondents was also higher from conventional banks i.e. $93.7 \%$ and much lower from Islamic banks i.e. $6.3 \%$. Thus, this study has a limitation with regard to number of respondents from Islamic banks included in this study and would not be generalize able to this category of banks. Further, we have 159 (55.8\%) respondents from manager grade, while other 126 (44.2\%) were from non manager grade for level of job. Gender distribution indicates a lower number of female respondents i.e. $45(15.8 \%)$ that could be due to the less number of employments of females in the banking sector of Pakistan. For qualification $55.8 \%$ of the respondents were master degree holders, $36.8 \%$ were graduate degree holders, while remaining $7.4 \%$ did some diploma/ course like ACCA etc.

Table 2 provides the numerical demographics for the respondents included in the study i.e. Total job experience, Experience with current bank and Age of the respondents. The average respondent in the study had 7.73 years of experience in the banking sector with minima of one year and maxima of 25 years while standard deviation of 5.5 indicates that the sample is well scattered around mean value. Same is the case with variable Total experience with current bank, the mean value for this variable is 5.34 years with minima of 1 year and maxima of 23 years, and the standard deviation for this variable is 4.73 . For age variable mean value is 31.93 indicating that most of the respondents are from mature age group with minima of 21 years and maxima of 56 years with a standard deviation of 7.48 .

Table 3 entails the descriptive statistics of the study. A mean score of 3.47 for action learning which is the independent variable of the study, indicates above average prevalence of action learning technique of on the job training in the banks while standard deviation of .820 provides somewhat higher standard deviation indicating the difference of opinion of the employees with regard to use of action learning technique in the banking sector of Pakistan. Overall, the result favors the presence of the action learning technique to somewhat moderate level. Two dependent variables of the study are employee motivation and employee commitment. The mean value of 3.78 and 3.54 along with standard deviation of .566 and .520 respectively provides that employees of the banks are moderately motivated and committed, while motivation is the stronger phenomenon than commitment in banking sector.

Finally Table 4 above establishes the relationship between independent variable i.e. action learning and dependent variables i.e. employee motivation and employee commitment by means of correlation. As seen in the table, action learning has a significant positive indicator of both employee motivation and employee commitment. Both relationships are significant at $1 \%$ level of significance so we accept both of our hypothesis i.e. $\mathrm{H}_{1}$ and $\mathrm{H}_{2}$ stating that action learning has a significant relationship with employee motivation and employee commitment. The relationship however, seems to be weak as the beta values for both employee motivation and employee commitment is .226 and .219 respectively. Our findings endorse the earlier findings of (McGill and Beaty, 2001; Marquardt, 1997) who found a positive relationship between employee commitment and action learning and with (Eggers, Wooten, Childs, \& Coker, 2008; Katsanis, 2006) who established a positive relationship of action learning with employee motivation.

\section{Study Limitations and Implications for Future Research}

The current research study was conducted as one-shot study and hence may be affected by some recency affects. Moreover this study was conducted in only one sector i.e. banking sector and only with highly qualified graduate and postgraduate bankers such as managers, customer service officers (CSOs) and business development officers (BDOs), in order to generalize the results of current research study, this study should be replicated in other sectors irrespective of the level of job and qualifications of the respondents in future. Also no comparison was made among different conventional and non-conventional banks as well as demographic characteristics of the sample population; any variation in these factors may affect the findings of the study. Moreover unit of analysis of the current study was the individual employee. Future research might carry out the analysis at the group or organization levels in order to compare the results within and between organizations.

\section{Conclusions and Discussions}

Action learning is gaining popularity as an on-the-job training method in the corporate sector around the world due to demand of the dynamic and competitive business environment which requires unique competencies, skills and experience of the employees in order to cope up with the challenging work routine. Action learning provides the solution with regard to learning and training of the employees both in terms of efficiency and effectiveness along with minimal costs of such training programs. The action learning along with building skill of the employees may affect other organization related variables such as employee commitment and employee motivation (Eggers, 
Wooten, Childs, \& Coker, 2008; Moczuk, 2006; Cortada, \& Woods, 1999; Goh, 1998). The purpose of this research is to provide empirical grounds to this proposition for the banking sector of Pakistan.

Conducting 285 valid surveys and establishing relationships by means of correlation we provide evidence of a positive impact of action learning on both employee commitment and employee motivation in the banking sector of Pakistan. This imply that tool of action learning has two fold effects if applied. One it has a potential to increase the skills and experiences of the employees, second, it could contribute positively towards the organization related behaviors such as employee commitment and employee motivation. So, the HR manager of banking sector should consider formal action learning plans while designing the training procedure of the corporations to sow the action learning in the culture of the organization.

\section{References}

Armstrong, M. (2006). Motivation. A Handbook of Human Resource Management Practice (pp. 253-254). London: Kogan Page Limited.

Baldwin, T. T., Magjuka, R. J., \& Loher, B. T. (1991). The perils of participation: effects of choice of training on trainee motivation and learning. Personnel Psychology, 44, 51-65. http://dx.doi.org/10.1111/j.1744-6570.1991.tb00690.x

Beaty, L., Lawson, J., Bourner, T., \& O’Hara, S. (1997). Action learning comes of age - Part 3: action learning for what?. Education and Training, 39 (4/5), 184-188.

Berman, E. M., Bowman, J. S., West, J. P., \& Wart, M. R. V. (2010). Motivation: Possible, Probable or Impossible?. Human Resource Management in Public Service: Paradoxes, Processes and Problems (pp. 180). California: SAGE Publications, Inc.

Cooper, H., Robinson, J. C., \& Patall, E. A. (2003). Does homework improve academic achievement? A synthesis of research, 1987-2003. Review of Educational Research, 76 (1), 1-62. http://dx.doi.org/10.3102/00346543076001001

Cortada, J. W., \& Woods, J. A. (1999). Knowledge-Based Strategies. The Knowledge Management Yearbook 1999-2000 (pp. 141-142). Woburn, MA: butterworth-Heinemann.

DeCenzo, D. A., \& Robbins, S. P. (1996). Human resources management. New York: John Wiley \& Sons, Inc.

Dilworth, R. L., \& Willis, V. J. (2003). Action Learning and Pathways. Malabar, FL: Krieger Publishing Company.

Eggers, J. D., Wooten, T., Childs, B., \& Coker, J. (2008). Evidence on the Effectiveness of On-Line Homework. College Teaching Methods \& Styles Journal, 4 (5), 9-16.

Fernet, C., Senecal, C., Guay, F., Marsh, H., \& Dowson, M. (2008). The Work Tasks Motivation Scale for Teachers (WTMST). Journal of Career Assessment, $16 \quad$ (2), 256-279. http://dx.doi.org/10.1177/1069072707305764

Ferris, G. R., Rosen, S. D., \& Barnum, D. T. (1995). Management Development in a new reality. Handbook of human resource management (pp. 520). Oxford: Blackwell Publishers Ltd.

Frank, H. D. (1996). The use of action learning in British higher education. Education and Training, 38 (8), 7-15. http://dx.doi.org/10.1108/00400919610146270

Gilley, J. W., \& Maycunich, A. (2000). Training, Learning and Developmental Organizations. Beyond the Learning Organization: Creating a Culture of Continuous Growth and Development through State-of-the-Art Human Resource Practices (pp. 15-17). USA: Perseus Books Group.

Goh, S. C. (1998). Toward a Learning Organization: The Strategic Building Blocks. SAM Advanced Management Journal, 63, 15-22.

Hibbert, L. (2000). Practical makes perfect. Professional Engineering, 13 (17), 49-51.

Islam, R., \& Ismail, A. Z. H. (2008). Employee motivation: a Malaysian perspective. International Journal of Commerce and Management, 18 (4), 344-362. http://dx.doi.org/10.1108/10569210810921960

Johnson, C., \& Spicer, D. P. (2006). A case study of action learning in an MBA program. Education + Training, 48 (1), 39-54.

Kamery, R. H. (2004). Motivational Techniques for Positive Reinforcement: A Review. Allied Academies International Conference. 8 (2), 91-96.

Katsanis, L. P. (2006). An assessment of professional training for product managers in the pharmaceutical industry. Journal of Product \& Brand Management, 15 (5), 324-330. http://dx.doi.org/10.1108/10610420610685721 
Knudsen, C. W., \& Smith, C. C. (1934). The Evaluation of Assignments. Junior-Senior High School Clearing House, 8 (7), 394-399.

Lord, R. L. (2002). Traditional motivation theories and older engineers. Engineering Management Journal, 14 (3), $3-7$.

Marquardt, M. (1997). Implementing Action Learning. Action Learning Infoline: Tips, Tools \& Intelligence for Trainers (pp. 6). USA: ASTD press.

Marquardt, M. J. (2004). Emergence of the Power of Action Learning. Optimizing the Power of Action Learning: Solving Problems and Building Leaders in Real Time (pp. 1-4). USA: Davies-Black Publishing.

McGill, I., \& Beaty, L. (2001). Doing Action Learning. Action learning: a guide for professional, management \& education development (pp. 25-27). London: Kogan Page Limited.

Mercer, J. R. (1990). Action learning: a student's perspective. Industrial and Commercial Training, 22 (2), 3-8.

Moczuk, D. B. (2006). Encouraging students' lifelong learning through graded information literacy assignments. Reference Services Review, 34 (4), 498-508. http://dx.doi.org/10.1108/00907320610716404

Mohsan, F., Nawaz, M. M., \& Khan, M. S. (2011). Coaching as a Predictor of Motivation and Job Involvement: Evidence from Banking Sector of Pakistan. European Journal of Social Sciences, 22 (3), 406-413.

Mowday, R., \& Steers, R. M. (1979). The Measurement of Organizational Commitment. Journal of Vocational Behavior, 224-47. http://dx.doi.org/10.1016/0001-8791(79)90072-1

Mumford, A. (1995). Learning in action. Industrial and Commercial Training, 27 (8), 36-41. http://dx.doi.org/10.1108/00197859510097081

Nelson, B. (1996). Dump the cash, load on the praise. Personnel Journal, 75 (7), 65.

Ng, T. W. H., Butts, M. M., Vandenberg, R. J., Dejoy, D. M., \& Wilson, M. G. (2006). Effects of management communication, opportunity for learning, and work schedule flexibility on organizational commitment. Journal of Vocational Behavior, 68 (3), 474-489. http://dx.doi.org/10.1016/j.jvb.2005.10.004

O'Hara, S., Webber, T., \& Reeve, S. (1996). Action learning in management education. Education and Training, 38 (8), 16-21. http://dx.doi.org/10.1108/00400919610146289

Osteraker, M. C. (1999). Measuring motivation in a learning organization. Journal of Workplace Learning, 11 (2), 73-77. http://dx.doi.org/10.1108/13665629910260798

Pedler, M. (1996). Action Learning for Managers. London: Lemos and Crane.

Pollanen, M. (2007). Improving Learner Motivation with Online Assignments. Merlot Journal of Online Learning and Teaching, 3 (2), 203-213.

Potter, B. N., \& Johnston, C. G. (2006). The effect of interactive on-line learning systems on student learning outcomes in accounting. Journal of accounting education. 24 (1), 16-34. http://dx.doi.org/10.1016/j.jaccedu.2006.04.003

Pounder, T. (2009). Using action learning to drive organizational learning and performance. Strategic Hr Review, 8 (3), 17-23. http://dx.doi.org/10.1108/14754390910946530

Raelin, J. A. (1997). Individual and situational precursors of successful action learning. Journal of Management Education, 21 (3), 368-94. http://dx.doi.org/10.1177/105256299702100308

Revans, R. (1980). Action Learning: New Techniques for Managers. London: Blond \& Briggs.

Robbins, S. P., \& Coulter, M. (1996). Management. Englewood Cliffs, NJ: Prentice Hall, Inc.

Sandelands, E. (1998). Creating an online library to support a virtual learning community. Internet Research: Electronic Networking Applications and Policy, 8 (1), 75-80. http://dx.doi.org/10.1108/10662249810368923

Wagner, J. A., \& Gooding, R. Z. (1987). Shared influence and organizational behavior: a Meta analysis of situational variables expected to moderate participation-outcome Relationships. Academy of Management Journal, 30, 524-41. http://dx.doi.org/10.2307/256012

Weinstein, K. (1998). Action Learning: A Journey in Discovery and Development. Glasgow: Harper Collins. 
Table 1. Demographics (Categorical)

\begin{tabular}{|l|lcc|}
\hline Demographics & Category & $\begin{array}{c}\text { No. of respondent in } \\
\text { category }\end{array}$ & Percentage \\
\hline Type of bank & Public & 24 & \\
& Private & 261 & 8.4 \\
& Total & 285 & 91.6 \\
& & 267 & 100 \\
\hline Nature of Bank & Conventional & 18 & 93.7 \\
& Islamic & 285 & 6.3 \\
& Total & & 100 \\
\hline Level of job & & 159 & \\
& Manager Grade & 126 & 55.8 \\
& Non manager grade & 285 & 44.2 \\
& Total & & 100 \\
\hline Gender & & 240 & 84.2 \\
& Male & 45 & 15.8 \\
& Female & 285 & 100 \\
& Total & & 36.8 \\
& & 105 & 55.8 \\
& Graduation & 159 & 7.4 \\
& Masters & 21 & 100 \\
\hline
\end{tabular}

Table 2. Demographics (Numerical)

\begin{tabular}{|l|cccc|}
\hline & Minimum & Maximum & Mean & Std. Deviation \\
\hline Total Job Experience & 1.00 & 25.00 & 7.7368 & 5.55804 \\
Total Experience With & 1.00 & 23.00 & 5.3368 & 4.72693 \\
Current Bank & 21.00 & 56.00 & 31.9263 & 7.48130 \\
Age & & & & \\
\hline
\end{tabular}

Table 3. Summary statistics of dependent and independent variables used in the study

Table 4. Correlations

\begin{tabular}{|l|c|c|}
\hline & Mean & Std. Deviation \\
\hline Action Learning & 3.47 & .820 \\
\hline Employee Motivation & 3.78 & .566 \\
\hline Employee Commitment & 3.54 & .520 \\
\hline
\end{tabular}

\begin{tabular}{|l|l|c|c|}
\hline & & $\begin{array}{c}\text { Employee } \\
\text { Motivation }\end{array}$ & $\begin{array}{c}\text { Employee } \\
\text { Commitment }\end{array}$ \\
\hline Action Learning & Pearson Correlation & $.226^{* *}$ & $.219^{* *}$ \\
\cline { 2 - 4 } & Sig. (2-tailed) & .000 & .000 \\
\hline
\end{tabular}

** Significant at 0.01 level of significance 


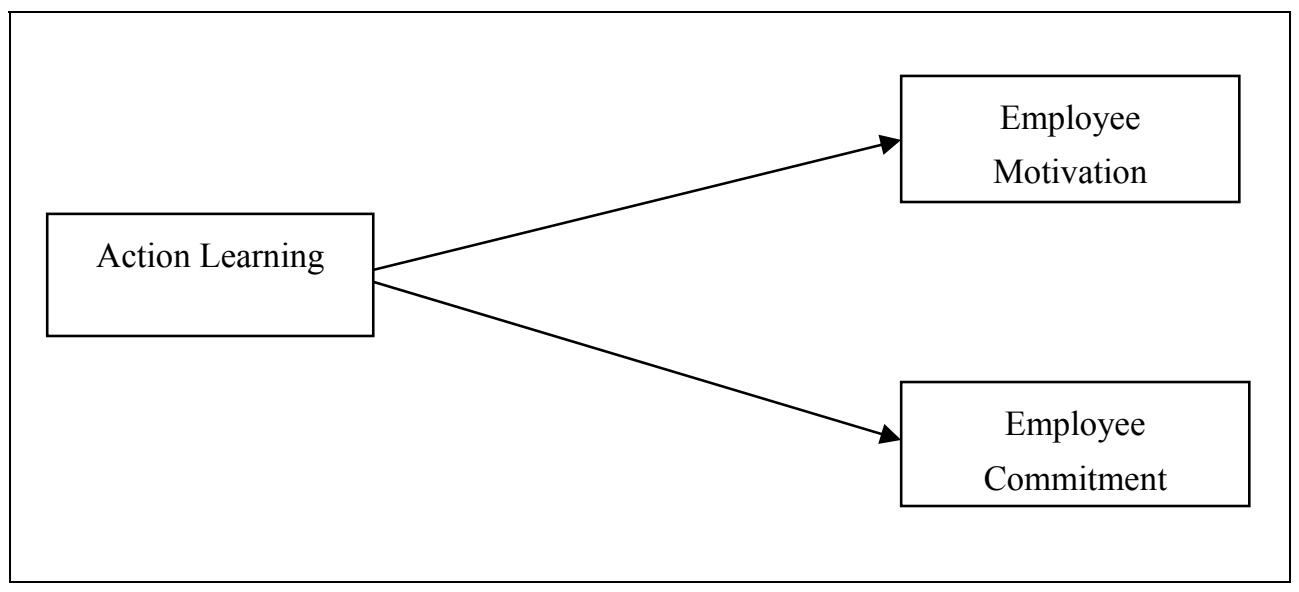

Figure 1. Theoretical Framework of the Study 